\author{
Sustinere \\ Journal of Environment and Sustainability \\ Volume 1 Issue 2 (2017) 99 - 108 \\ Print ISSN: 2549-1245 Online ISSN: 2549-1253 \\ Website: https://sustinerejes.com E-mail: sustinere.jes@iain-surakarta.ac.id
}

\title{
RESEARCH PAPER \\ The strategy of domestic wastewater management in Kenjeran Surabaya
}

Daniel Wicaksono*, Agus Slamet

Department of Environmental Engineering, Faculty of Civil Engineering and Planning, Institut Teknologi Sepuluh Nopember (ITS) Surabaya, Indonesia

Article history:

Received 2 August 2017 | Accepted 20 October 2017 | Available online 29 December 2017

\begin{abstract}
Kenjeran is one of the districts in Surabaya with high-risk sanitation based on EHRA Surabaya 2012. Kenjeran has 4 (four) sub-districts that consists of Bulak Banteng, Tanah Kali Kedinding, Sidotopo Wetan, and Tambak Wedi. Bulak Banteng, Tanah Kali Kedinding, and Tambak Wedi have been identified as the areas in which open defecation still happened. The research is descriptive study by using field survey, interview, and comparison of existing condition with standards and regulations. The technical aspect study is conducted by analyzing the needs of wastewater infrastructure facilities based on the volume of domestic wastewater. 80 (eighty) Communal Sewage Treatment Plant (STP) were designed to solve domestic wastewater handling in 4 (four) sub-districts. Each of 80 (eighty) STP was designed to cover $75-100$ households. The domestic wastewater treatment used Anaerobic Baffled Reactor Technology. An example of STP design was conducted in Dukuh Bulak Banteng with the coverage of 100 households.
\end{abstract}

Keywords: Domestic Wastewater; Anaerobic Baffle Reactor

\section{Introduction}

The Government of Indonesia will enter the new National Medium Term Development Plan (Rencana Pembangunan Jangka Menengah National, RPJMN) 2015-2019 which sets a new target of universal access to accessible sanitation by the end of 2019 in the form of $100 \%$ fulfillment of clean water, $0 \%$ slum area and $100 \%$ sanitation access. In an effort to achieve these targets it is felt the importance of having a sustainable sanitation strategy.

Surabaya as a Metropolis which is also the capital of East Java province consists of 31 districts that have a population of 2,977,520 inhabitants (BPS, 2015). Kenjeran is one of the districts in Surabaya with high risk sanitation. Kenjeran has four sub-districts that have been identified as the areas in which open defecation still happened.

The development of wastewater infrastructure and education of sanitation for public is one of the efforts to manage the wastewater treatment in Kenjeran. These developments 
will have a good impact in public health. This research will identify suitable strategies for domestic wastewater management in Kenjeran. The analysis of domestic wastewater management strategies is assessed on the technical aspect.

\section{Review of the literature}

\subsection{Domestic wastewater management system}

The wastewater treatment system according to Tchobanoglous (1981) consists of collecting, transmission, and treatment systems. Domestic wastewater management system can be done by onsite system and offsite system. Influencing factors that affect the wastewater management are demography and technical handling.

The population density levels commonly used in wastewater systems management are high density less than 300 persons/ha, medium density of $100-300$ persons/ha, low density less than 100 persons/ha. Population density more than 300 persons/ha use the septic tanks with absorption well that potentially cause contamination of pathogenic bacteria on soil and ground water. The communal wastewater system management is more economical and efficient in the coverage of densely populated areas. In general, the strategy directions of handling wastewater management system are as follows:

- The amount of BOD parameter in wastewater must be lower

- Selection of densely populated areas that need to be applied with wastewater management system

- Determining the scale of treatment based on economic considerations and specifying the type of wastewater management system to be used for densely populated areas.

Meanwhile, the technical handling of waste water was intended for building inlet, outlet process meet the essence of health includes the distance of the septic tank infiltration field with the source of drinking water shall be maintained with a distance more than 10 meters for clay type and more than 15 meters for sand soil; the density of 100 people/ha using individual septic tank may affect contamination coli bacteria on soil and ground water. Thus, for individual sanitary users in the area of such density, the application of anaerobic filters in lieu of the infiltration field and its effluents may be discharged into open channels, or communal using off site sanitation systems.

\subsection{Domestic wastewater treatment technology}

\section{Septic tank}

The SNI 03-2398-2002 about the procedure of septic tank planning with recharge system is as follows. First, building materials must be strong. Second, it has to be resistant to acid and waterproof. Third, building materials that can be selected for basic building, cover and sewage pipes are stone, red brick, brick, ordinary concrete, reinforced concrete, asbestos cement, PVC, ceramic and iron plate. Fourth, length ratio (P) and width (L), (2-3: 1), with minimum width of 0.75 meters, minimum length of 1.5 meters, tank height of at least 1-5 meters including 0.3 meters threshold. Septic tanks also require sufficient land from water sources to avoid water source contamination. The distance of the catchment system to the water source is more than 10 meters. 


\section{Anaerobic baffled reactor}

Anaerobic baffled reactor (ABR) is a modified septic tank technology by adding several compartments to generate up flow through anaerobic sludge and increase the contact time between active biomass and wastewater. The advantages using ABR are it is able to treat high organic load wastewater, it has easy operation and maintenance and also produces biogas that can be utilized as an energy source.

The design of ABR based on the following design criteria and technical requirements are available land for ABR where it is easy to construction, operate and maintain, can be used on communal scale and ABR used as preliminary treatment if the concentration of BOD more than $300 \mathrm{mg} /$ liters.

Table 1. Design Criteria ABR

\begin{tabular}{lc}
\hline \multicolumn{1}{c}{ Parameter } & Criteria \\
\hline Velocity & $<2 \mathrm{~m} / \mathrm{hour}$ \\
Removal COD & $65-90 \%$ \\
Removal BOD & $70-95 \%$ \\
Organic Loading & $<3 \mathrm{~kg} \mathrm{COD} / \mathrm{m}^{2}$.day \\
Hydraulic Retention Time & $6-20$ hours \\
Organic Loading Rate & $0,1-8 \mathrm{~kg} \mathrm{COD} / \mathrm{m}^{2}$.day \\
\hline
\end{tabular}

Figure 1. Typical ABR Reactor

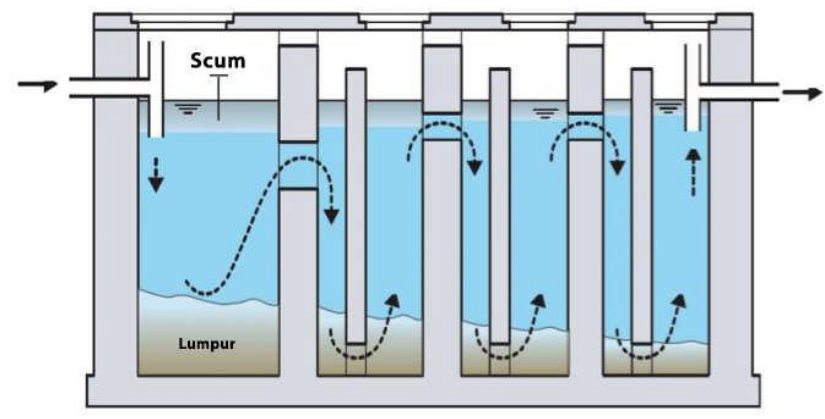

\section{Sewerage system}

Based on sewerage design criteria (MPUPR, 2017), there are 3 types of sewerage, i.e. small bore sewer, shallow bore sewer, and conventional sewer.

\section{Small bore sewer}

Small Bore Sewer is suitable for areas with medium to high density (more than 200 person/ha), especially for the areas that have been using septic tank but the surrounding soil is no longer able to absorb the effluent from septic tank. The components of small bore sewer consists of household, septic tank, sewer, manhole, and pumping (if needed). The standard criteria of small bore sewer are minimum pipe diameter is of $100 \mathrm{~mm}$, maximum velocity in pipe is of $3 \mathrm{~m} / \mathrm{sec}$, and only receives effluent from septic tank and grey water, the existence of septic tank should be maintained. 


\section{Shallow bore sewer}

Shallow Bore Sewer is considered for the areas with high density and large populations that already have water supply. These system covers domestic wastewater that served by lateral pipe, service pipe and sewage treatment plant. The criteria of shallow bore sewer are used for high density population (more than 200 person/ha) in order to have sufficient volume of water for self-cleansing, suitable serve in low income areas, already have wastewater connections and should not have septic tank, the pipe diameter is of minimum $150 \mathrm{~mm}$, minimum velocity is of $0.5 \mathrm{~m} / \mathrm{second}$ and maximum velocity is of $3 \mathrm{~m} / \mathrm{second}$ and the minimum depth pipeline is of 0.4 meter.

\section{Conventional sewer}

A conventional gravity sewer system is used to collect wastewater from multiple sources and covey by gravity the wastewater to a treatment plant or other authorized point of discharge. The sewer pipelines are designed so that the slope and size of the pipe is adequate to maintain flow without surcharging manholes or pressurizing the pipe. The collection sewer pipelines are typically eight-inch or larger in diameter Pipes are installed with sufficient slope to keep the suspended solids moving through the system. If gravity flow is not possible throughout the system, lift stations are installed at lower elevations of the network in order to pump the sewage up to another gravity pipeline. Manholes are installed at regular intervals to provide maintenance access.

Proper maintenance includes periodic line repairs and inspection, cleaning out blockages, and repairing areas where significant infiltration is occurring. Gravity sewers in cluster or small community systems do not include septic tanks for primary treatment on each lot. Thus, the central treatment facility must provide primary treatment.

\section{Result and discussion}

Most of the land used in Kenjeran sub-district based on regulations Regional Regulation of Surabaya Spatial Plan in 2014-2034 is a settlement land. The available land is now limited due to the already built residential area and trade and services building.

Table 2. Population density based on building density in Kenjeran Surabaya

\begin{tabular}{lccc}
\hline \multicolumn{1}{c}{ Sub-district } & $\begin{array}{c}\text { Area } \\
\left(\mathrm{km}^{2}\right)\end{array}$ & Population & $\begin{array}{c}\text { Population density } \\
\text { (people/ha) }\end{array}$ \\
\hline Tanah Kali Kedinding & 2.41 & 52,678 & 219 \\
Sidotopo Wetan & 1.66 & 56,325 & 340 \\
Bulak Banteng & 2.67 & 30,660 & 115 \\
Tambak Wedi & 0.98 & 14,328 & 147 \\
\hline
\end{tabular}

Table 3. Population of Kenjeran, Surabaya residents in 2013-2016 (BPS, 2015; 2016)

\begin{tabular}{cc}
\hline Year & Population \\
\hline 2016 & 153,991 \\
2015 & 147,692 \\
2014 & 158,554 \\
2013 & 151.933 \\
\hline
\end{tabular}




\section{The source of domestic wastewater}

Fecal sludge

Based on standard criteria of the Ministry of Public Work (DPU, 2006), the range of fecal sludge amount from Water Closet into septic tank are between five to forty liters/person/day. The amount of mix black water and grey water range is $45-150$ liters/person/day. The calculation of fecal sludge is:

$$
Q=\text { Population people of Kenjeran in } 2017 \mathrm{x} \text { the amount of fecal sludge }
$$

Volume of fecal sludge and total mass of fecal sludge in each sub-district of Kenjeran are shown in Table 4.

Table 4. The volume and mass of fecal sludge

\begin{tabular}{lccc}
\hline \multicolumn{1}{c}{ Sub district } & $\begin{array}{c}\text { Population } \\
\text { (capita) }\end{array}$ & $\begin{array}{c}\text { Volume Fecal } \\
\text { Sludge (m3/day) }\end{array}$ & $\begin{array}{c}\text { Total Amount of } \\
\text { fecal sludge } \\
\text { (ton/day) }\end{array}$ \\
\hline Tanah Kali Kedinding & 52,678 & 263,390 & 9 \\
Sidotopo Wetan & 56,325 & 281,625 & 10 \\
Bulak Banteng & 30,660 & 153,300 & 5 \\
Tambak Wedi & 14,328 & 71,640 & 3 \\
\hline \multicolumn{1}{c}{ Total } & 153,991 & 769,955 & 28 \\
\hline
\end{tabular}

\section{Grey water}

The population of Kenjeran was multiplied by the consumption of fresh water, i.e. 150 liters/person/day. The wastewater discharge was $70 \%$ of the water consumption. The calculation of volume of grey water in Kenjeran is following the equation (2) and the results are shown in Table 5.

Debit Domestic Wastewater $=$ the population $\mathrm{x}$ consumption water $\mathrm{x} 70 \%$

Table 5. Domestic wastewater debit

\begin{tabular}{lccc}
\hline \multicolumn{1}{c}{ Sub-district } & $\begin{array}{c}\text { Population } \\
\text { (capita) }\end{array}$ & $\begin{array}{c}\text { Water Consumption (150 } \\
\text { liters/capita/day) }\end{array}$ & $\begin{array}{c}\text { Debit } \\
\text { wastewater, } \\
\text { (m3/day) }\end{array}$ \\
\hline Tanah Kali Kedinding & 52,678 & 7,902 & 5,531 \\
Sidotopo Wetan & 56,325 & 8,449 & 5,914 \\
Bulak Banteng & 30,660 & 4,599 & 3,219 \\
Tambak Wedi & 14,328 & 2,149 & 1,504 \\
\hline Total & 153,991 & 23,098 & 16,169 \\
\hline
\end{tabular}

\section{The coverage of communal sewage treatment plant}

Based on technical criteria in regulation Ministry of Public Work number 47 year 2015 , the range of offsite system of domestic wastewater management could be served 
between 50 persons until 1000 persons. The location that can be built for Communal STP is considered technical criteria that consist of the coverage Communal STP to serve minimum 50 households, the available land to build Communal STP, the availability of water bodies to receive effluent Communal STP, easy to operation and maintain communal STP and the resident that has risk sanitation domestic wastewater to prevent water pollution.

Eighty communal STP were designed to solve domestic wastewater handling in 4 (four) sub district. Each of 80 (eighty) STP designed to cover 75-100 households. The total of communal STP were planned in Kenjeran consists of 21 point locations STP in Tambak Wedi, 19 point locations STP in Bulak Banteng, 20 point locations STP in Sidotopo Wetan, 20 point locations in Tanah Kali Kedinding. Each of coverage service of STP was planned to serve one block of residential that considered build STP by underground street, high density population and easy to maintenance STP.

\section{The selection of communal sewage treatment technology}

Alternative IPAL technology will be done with the comparison of advantages and disadvantages and provide scores on each criterion are required. The highest score will indicate that the description can be applied shown in Table 6. Scoring in technology selection are score 3 (applicable), score 2 (can be applicable with conditions), and score 1 (can't be applied).

Based on the highest score of STP technology options in Table 7, the selected technology is anaerobic baffle reactor (ABR) with land considerations, low maintenance cost requirements, easy operation, and good effluent.

Table 6. Alternative Selection STP Technology

\begin{tabular}{|c|c|c|c|c|c|c|}
\hline \multirow[b]{2}{*}{ Description } & \multicolumn{2}{|l|}{ Alternative 1} & \multicolumn{2}{|c|}{ Alternative 2} & \multicolumn{2}{|c|}{ Alternative 3} \\
\hline & Bio filter & Score & $\begin{array}{l}\text { Anaerobic baffle } \\
\text { reactor }\end{array}$ & Score & Wetland & score \\
\hline Land & $\begin{array}{l}\text { Can be build } \\
\text { underground }\end{array}$ & 2 & $\begin{array}{l}\text { Can be build } \\
\text { underground }\end{array}$ & 3 & $\begin{array}{l}\text { Need a large } \\
\text { enough land }\end{array}$ & 1 \\
\hline $\begin{array}{l}\text { Operational \& } \\
\text { Maintenance }\end{array}$ & $\begin{array}{l}\text { Need routine to } \\
\text { clean filter. Low cost } \\
\text { of maintenance }\end{array}$ & 2 & $\begin{array}{l}\text { Easy to operate, } \\
\text { low cost of } \\
\text { maintenance }\end{array}$ & 3 & $\begin{array}{l}\text { Easy to operate, } \\
\text { low cost of } \\
\text { maintenance }\end{array}$ & 3 \\
\hline Construction & $\begin{array}{l}\text { Material Plant from } \\
\text { concrete, material is } \\
\text { easy to get }\end{array}$ & 2 & $\begin{array}{l}\text { Material Plant } \\
\text { from concrete, } \\
\text { material is easy } \\
\text { to get }\end{array}$ & 3 & $\begin{array}{l}\text { Material Plant } \\
\text { from concrete, } \\
\text { material is easy to } \\
\text { get }\end{array}$ & 3 \\
\hline $\begin{array}{l}\text { The need of } \\
\text { Operator }\end{array}$ & $\begin{array}{l}\text { No need } \\
\text { professional }\end{array}$ & 2 & $\begin{array}{l}\text { No need } \\
\text { professional }\end{array}$ & 3 & $\begin{array}{l}\text { No need } \\
\text { professional }\end{array}$ & 3 \\
\hline $\begin{array}{l}\text { Community } \\
\text { Participate }\end{array}$ & Can participate fully & 2 & $\begin{array}{l}\text { Can participate } \\
\text { fully }\end{array}$ & 3 & $\begin{array}{l}\text { Can participate } \\
\text { fully }\end{array}$ & 3 \\
\hline $\begin{array}{l}\text { The Effluent } \\
\text { STP }\end{array}$ & Good & 2 & Good & 3 & Good & 3 \\
\hline Total & & 17 & & 18 & & 16 \\
\hline
\end{tabular}




\section{Planning sewage treatment plant in Bulak Banteng, Kenjeran}

Dukuh Bulak Banteng settlement which is located near to Kali Tebu is one of the areas that open defecation still happened. Based on survey result that there are 100 (one hundred) houses where only have a latrines but the pipeline directly into Kali Tebu Bulak Banteng. These location has topography relatively flat with elevation between 3 masl and 4.5 masl. The land for construction STP was in an underground street next to drainage channel. The location STP planned could be shown in Figure 2.

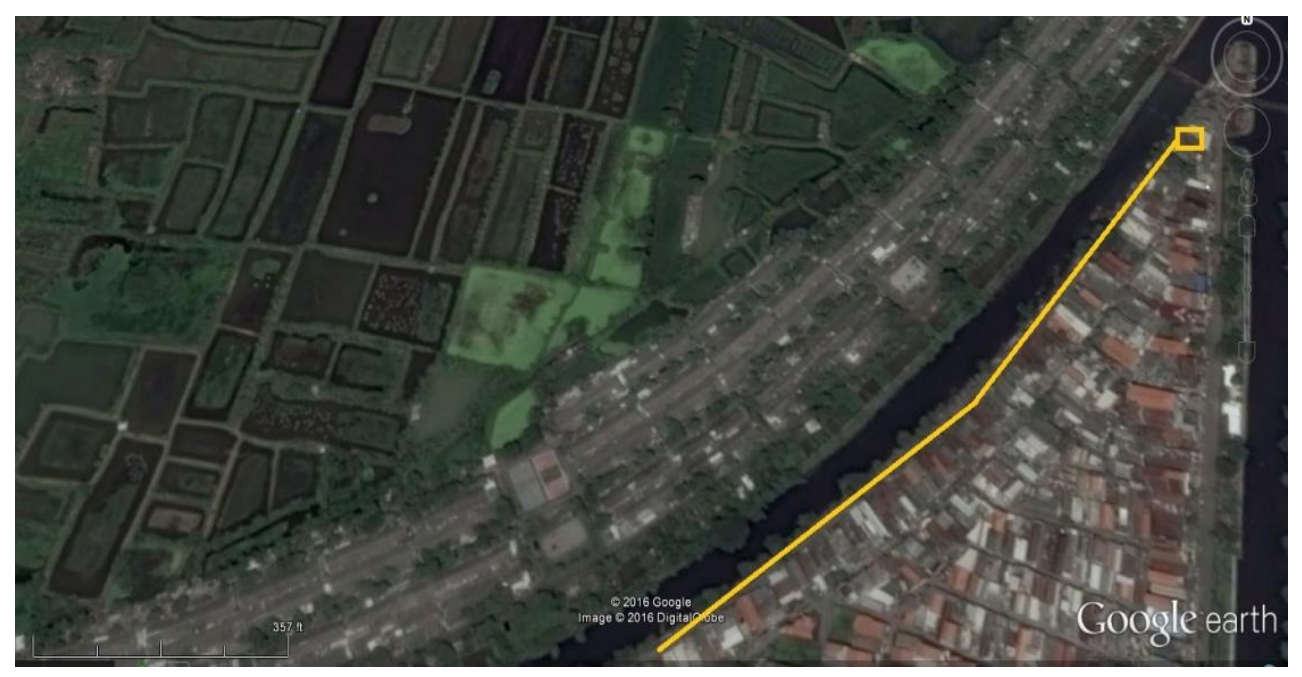

Notes: $\square$ location STP

- service coverage

Figure 2. Planning location of STP in Dukuh Bulak Banteng

ABR designed into several compartments where each compartment has the same length as one another. It aims to make stable flow and prevent the existence of excessive turbulence in each compartment. The calculation of mass balance is required to show result of effluent STP. The result STP can be shown in Table 7.

Table 7. Treatment process in ABR

\begin{tabular}{ccccc}
\hline Parameter & $\begin{array}{c}\text { Efficiency } \\
\text { ABR (\%) }\end{array}$ & $\begin{array}{c}\text { Influence } \\
\text { ABR } \\
(\mathrm{mg} / \mathrm{L})\end{array}$ & $\begin{array}{c}\text { Effluent } \\
\text { ABR } \\
(\mathrm{mg} / \mathrm{L})\end{array}$ & $\begin{array}{c}\text { Standards of Domestic } \\
\text { Wastewater * (mg/L) }\end{array}$ \\
\hline BOD & 93 & 142 & 10 & 30 \\
COD & 91 & 235 & 23.5 & 50 \\
TSS & 80 & 140 & 4.2 & 50 \\
\hline
\end{tabular}

Noted *: Regulation in East Java Governor Regulation Number 72 Year 2013

Table 7 describes that concentration of BOD, COD and TSS after treatment through $\mathrm{ABR}$ and the effluent $\mathrm{ABR}$ was allowed to be discharged into river. 


\section{Determination of sewerage}

The sewerage considers the current conditions at the site of planning, especially the characteristic of the ground elevation. The sewerage in settlements strength Kali Tebu using a small piping connected to the wastewater treatment plant. Sewerage through the collecting pipe to the next carrier pipe will go to the STP then the effluent of STP flowed into the river. The dimension of the collecting pipe is 4 inches $(10 \mathrm{~cm})$ in diameter and the carrier pipe is 6 inches $(15 \mathrm{~cm})$ in diameter. While the slope (Slope) used is $0.6 \%$. The result calculation of sewerage in Dukuh Bulak Banteng could be shown in Table 8.

Table 8. The result calculation diameter pipe domestic wastewater

\begin{tabular}{lcccccccc}
\hline \multirow{2}{*}{ Pipe } & Coefficient & d/D & $\begin{array}{c}\text { Qpeak/ } \\
\text { Qfull }\end{array}$ & $\begin{array}{c}\text { Qfull } \\
\left(\mathrm{m}^{3} / \mathrm{sec}\right)\end{array}$ & Slope & $\begin{array}{c}\text { Diameter } \\
(\mathrm{cm})\end{array}$ & \multicolumn{2}{c}{ Diameter used } \\
\hline A- B & 0.013 & 0.8 & 0.85 & 0.00077 & 0.006 & 5.59 & 6 & $\mathrm{Cm}$ \\
B-C & 0.013 & 0.8 & 0.85 & 0.00143 & 0.006 & 7.04 & 6 & 15.24 \\
C-D & 0.013 & 0.8 & 0.85 & 0.00220 & 0.006 & 8.27 & 6 & 15.24 \\
D-IPAL & 0.013 & 0.8 & 0.85 & 0.00281 & 0.006 & 9.07 & 6 & 15.24 \\
\hline
\end{tabular}

\section{Determination of design ABR}

Designed STP with coverage of 100 home connections serving a population of 480 people. Based on the data of PDAM Kota Surabaya (2016), the average consumption of Surabaya residents' water reaches 150 - 190 liters/person/day. The volume of domestic waste water generated is $70 \%$ of water consumption. The following is the calculation of wastewater treatment buildings:

$$
\begin{array}{ll}
\text { Household } & =100 \mathrm{HH} \\
\begin{array}{ll}
\text { Population } & =100 \mathrm{KK} \times 4 \text { capita } / \mathrm{HH}=400 \mathrm{HH} \\
\text { Water consumption } & =150 \text { liter } / \text { capita } / \text { day }
\end{array} \\
\begin{aligned}
\text { Wastewater Percentage } & =70 \% \\
\text { Wastewater flows }=150 & \text { liter } / \text { capita } / \text { day x } 400 \text { capita } \times 0.7 \\
& =42 \mathrm{~m}^{3} / \text { day } \\
& =1.75 \mathrm{~m}^{3} / \text { hour }
\end{aligned}
\end{array}
$$

Design Compartment

Design Criteria ABR (Sasse, 2009)

$\begin{array}{ll}\text { Velocity } & =<2 \mathrm{~m} / \text { hour, Used } 1.8 \mathrm{~m} / \text { hour } \\ \text { Detention time (Td) } & =\geq 6 \text { hours, Used } 10 \text { hours } \\ \text { Depth of compartment } & =2.5 \text { meters } \\ \text { Length of compartment } & =50 \% \text { until } 60 \% \text { depth, used } 50 \% \\ \text { Area of each compartment } & =1 \mathrm{~m}^{2} \\ \text { Length of compartment } & =1.25 \text { meter } \\ \text { Width of compartment } & =1.5 \text { meter }\end{array}$


The calculation compartment

Freeboard $\quad=0.3 \mathrm{~m}$

Volume each compartment $=5.3$ meter

Total volume ABR $=23.25 \mathrm{~m}^{3}$

The amount of compartment $=4$ compartments

Check organic loading rate $\quad=0.28 \mathrm{~kg} \mathrm{COD} / \mathrm{m}^{3}$ day-

Total dimension anaerobic baffled reactor

Length $=1.25 \mathrm{~m} \mathrm{x} 4$ compartments $=6$ meter

Width $=1.5$ meter

Depth $=2.5 \mathrm{~m}+0.3 \mathrm{~m}=2.8 \mathrm{~m}$

Dimension settler anaerobic baffle reactor

$\begin{array}{ll}\text { Depth } & =2.5 \mathrm{~m} \\ \text { Width } & =1.5 \mathrm{~m} \\ \text { Detention time at settler } & =3 \mathrm{jam} \\ \text { Sludge volume } & =4 \mathrm{~m}^{3} \\ \text { Wastewater volume } & =10.5 \mathrm{~m}^{3} \\ \text { Total volume } & =14.5 \mathrm{~m}^{3} \\ \text { Length } & =4 \mathrm{~m}\end{array}$

Calculation collection chamber

Design criteria collection chamber

Detention time $\quad=10$ minutes

Amount $\quad=1$ (one) unit

Flow $\quad=3.5 \mathrm{~m}^{3} /$ hour $=0.06 \mathrm{~m}^{3} /$ minute

Depth $\quad=1 \mathrm{~m}$

Area of compartment $=0.6 \mathrm{~m}^{2}$

Length: width ratio $\quad=1: 1$

$\begin{array}{ll} & =0.8 \mathrm{~m} \\ \text { Volume } & =0.6 \mathrm{~m}^{3}\end{array}$

\section{Calculation Pump}

- Debit (Q)

- Pipe

: $1 \mathrm{l} / \mathrm{seconds}$

- Velocity

: 1 unit

- Elevation

$: 1.25 \mathrm{~m} / \mathrm{Sec}$

- Pump

: $3.8 \mathrm{~m}$

- Length of pipe

: Submersible Pump

- C pipe PVC

: $3.7 \mathrm{~m}$

$: 120$ 


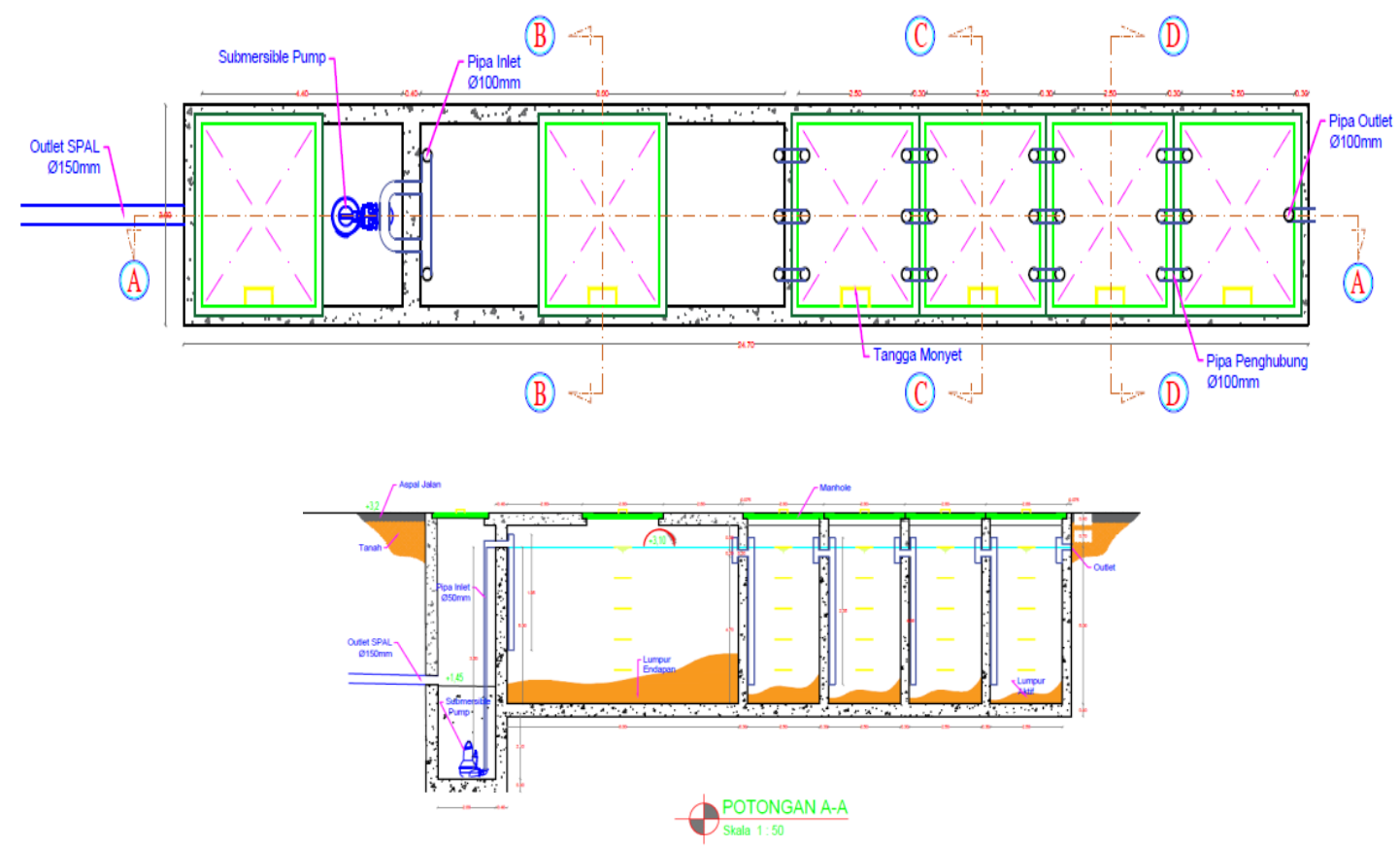

Figure 3. Layout anaerobic baffle reactor

\section{Conclusion}

After analyzing the data, the researchers conclude that 80 (eighty) Communal Sewage Treatment Plant (STP) were designed to solve domestic wastewater handling in 4 (four) sub district. Each of 80 (eighty) STP was designed to cover 75 - 100 households. The domestic wastewater treatment plant was designed using Anaerobic Baffled Reactor Technology.

\section{Acknowledgement}

We would like to express our greatest gratitude to the Government of Surabaya for permitting us to conduct our research in its region and providing us relevant data for this research.

\section{References}

DPU (2006). Kriteria Teknis Prasarana dan Sarana Pengelolaan Air Limbah, Departement Pekerjaan Umum, Direktorat Jenderal Cipta Karya, Jakarta.

BPS (2015), Kecamatan Kenjeran Dalam Angka 2015, Balai Pusat Statistik Kota Surabaya.

BPS (2016), Kecamatan Kenjeran Dalam Angka 2016, Balai Pusat Statistik Kota Surabaya.

MPUPR (2017), Penyelenggaraan Sistem Pengelolaan Air Limbah Domestik, Permen Pekerjaan Umum dan Perumahan Rakyat Nomor 04 Tahun 2017, Menteri Pekerjaan Umum dan Perumahan Rakyat, Jakarta.

Tchobanoglous, C. (1981). Wastewater engineering: Collection and pumping of wastewater. In Wastewater engineering: collection and pumping of wastewater. McGraw-Hill Book. 